\title{
A Hematite Cone from Smith County, Texas
}

\section{Mark Walters}

Heritage Research Center, Stephen F. Austin State University

Follow this and additional works at: https://scholarworks.sfasu.edu/ita

Part of the American Material Culture Commons, Archaeological Anthropology Commons, Environmental Studies Commons, Other American Studies Commons, Other Arts and Humanities Commons, Other History of Art, Architecture, and Archaeology Commons, and the United States History Commons

Tell us how this article helped you.

This Article is brought to you for free and open access by the Center for Regional Heritage Research at SFA ScholarWorks. It has been accepted for inclusion in Index of Texas Archaeology: Open Access Gray Literature from the Lone Star State by an authorized editor of SFA ScholarWorks. For more information, please contact cdsscholarworks@sfasu.edu. 


\section{A Hematite Cone from Smith County, Texas}

Creative Commons License

(c) (i) (8)

This work is licensed under a Creative Commons Attribution-NonCommercial 4.0 International License 


\title{
A Hematite Cone from Smith County, Texas
}

\author{
Mark Walters
}

\section{INTRODUCTION}

Hematite (Fe2O3) is a mineral, its most important usage being iron ore (Kraus et al. 1951). In the United States, hematite occurs over a large region with a major concentration in the central part of the country (Figure 1). Hematite has varying degrees of hardness and colors. Hematite gives rocks their red color and characteristic "red-streak." Soft, earthy (red ocher) forms were prized as paints. Hard, compact forms with considerable iron content were valued as tools, because of their strength as well as susceptibly to a high and beautiful polish. Certain forms of hematite are used in making jewelry. During prehistoric times, hematite was fashioned and used in a wide variety of forms including celts, axes, pendants, plummets, pestles, discoidals, cup stones (nutting stones), manos, and cones (Figure 2). The high degree of workmanship on some of these tools, and the absence of use-damage, suggest that some of them may have had uses that were other than merely functional.

This study concerns a hematite cone that was found in eastern Smith County, Texas along Prairie Creek (41SM449). I also discuss a possible unfinished hematite cone found at the Brieger Point site (41CP42) at Lake Bob Sandlin. Prehistoric hematite objects are not uncommon in East Texas, the most common forms being grooved axes (Turner 2006), celts, nutting stones, and manos. More uncommon are objects such as pendants and plummets. The hematite cone from the Prairie Creek site and the possible hematite cone from the Lake Bob Sandlin area are the only examples of hematite cones that I am aware of from the East Texas area. Hematite cones are more plentiful in the Ohio valley (Moorehead 1912). Their function is unknown, although it has been surmised that they may have been gaming pieces or talismans (Figure 3).

\section{PRAIRIE CREEK (41SM449) HEMATITE CONE}

The Prairie Creek cone was found on the surface of a sandy upland setting overlooking Prairie Creek (Figure 4). Prairie Creek flows 12 miles east to the Sabine River. The only other prehistoric artifact noted at the site was a ferruginous sandstone nutting stone. The nutting stone was roughly formed with a shallow circular depression on the top and bottom. There are examples of hematite cup stones (nutting stones) and manos with highly polished surfaces from a site only a couple miles away (Walters 2006). It is not known if the hematite cone and nutting stone at the Prairie Creek site (41SM449) were associated with each other. The nutting stones are fairly ubiquitous in this area, with a long history of use from Archaic through Caddo time periods.

The Prairie Creek cone is a dark reddish-brown (5YR2.5/2) color and highly polished. The object is shaped like a "Hershey's Kiss" (Figure 5). The base is flat and almost a perfect circle, measuring 60.5 $\mathrm{mm}$ in diameter from top to bottom and $60.2 \mathrm{~mm}$ in diameter from side to side (Figure 6a). In profile, the cone measures $18.2 \mathrm{~mm}$ at the nipple. The cone weighs $79.9 \mathrm{~g}$. While highly polished, the Prairie Creek cone exhibits small hair-line cracks leading to a process termed exfoliation (Figure 6b). This process is common on objects/tools made from hematite and is explained in detail by Turner (2006) in a study of hematite axes. 


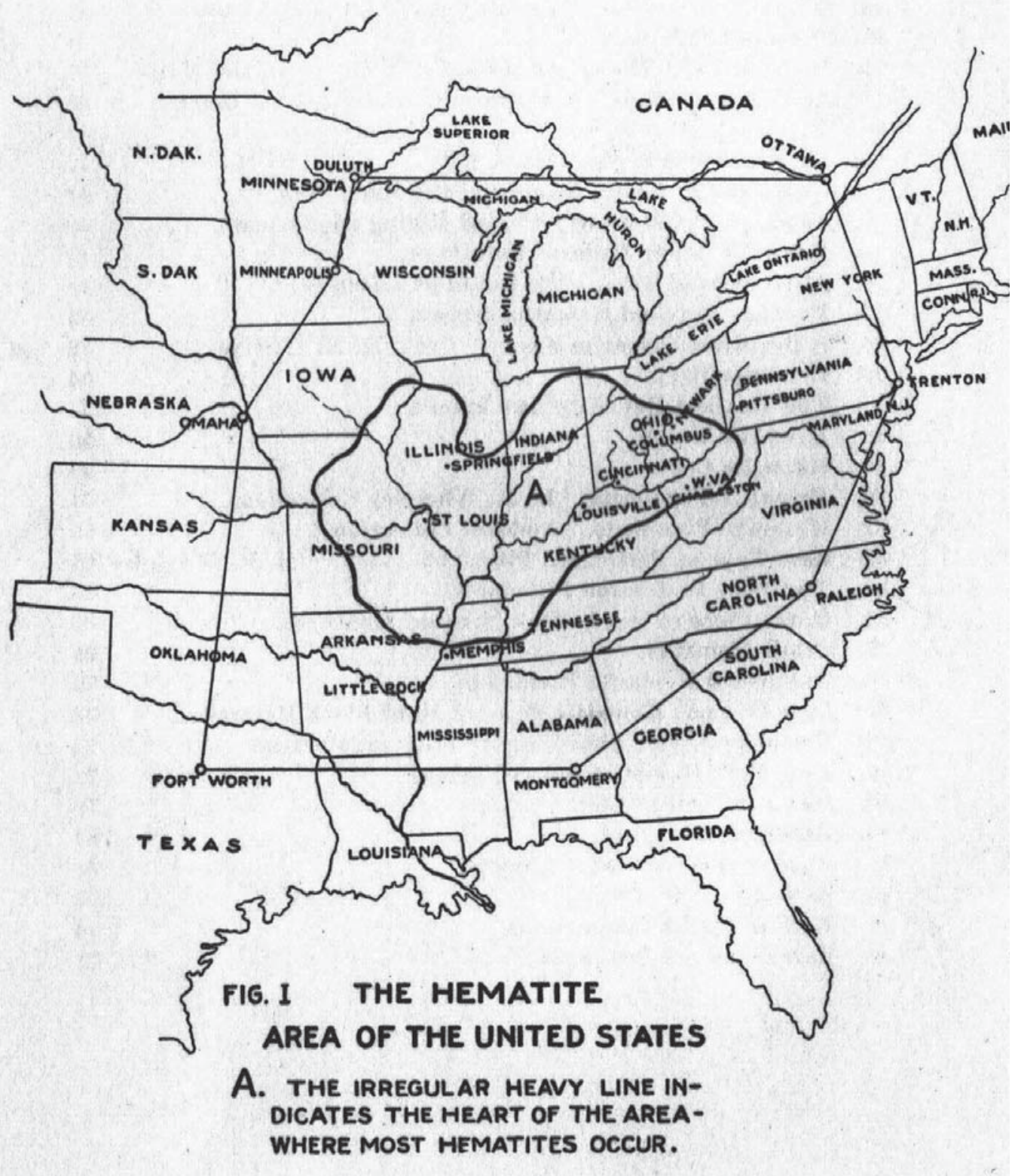

Figure 1. Moorehead's (1912) map of the hematite area.

\section{BRIEGER POINT (41CP42) CONE FROM LAKE BOB SANDLIN}

The Brieger Point cone was found on the surface of a site that has a long history of prehistoric occupation, but there are substantial Late Archaic and Woodland period components (Nelson and Perttula 2003:18-20). The Brieger Point cone is a reddish-brown (5YR4/4) hematite with patches of dark reddishbrown (5YR3/4) cortex. One surface is convex with numerous flake scars (Figure 7a). The thickness in profile is $15.9 \mathrm{~mm}$. The opposite surface is relatively flat and smooth with few flake scars around the edges to form a circle (Figure 7b). This indicates that the maker of the cone chose a piece of hematite of suitable size and shape to begin the process, then worked it down to a preform that had the desired object 


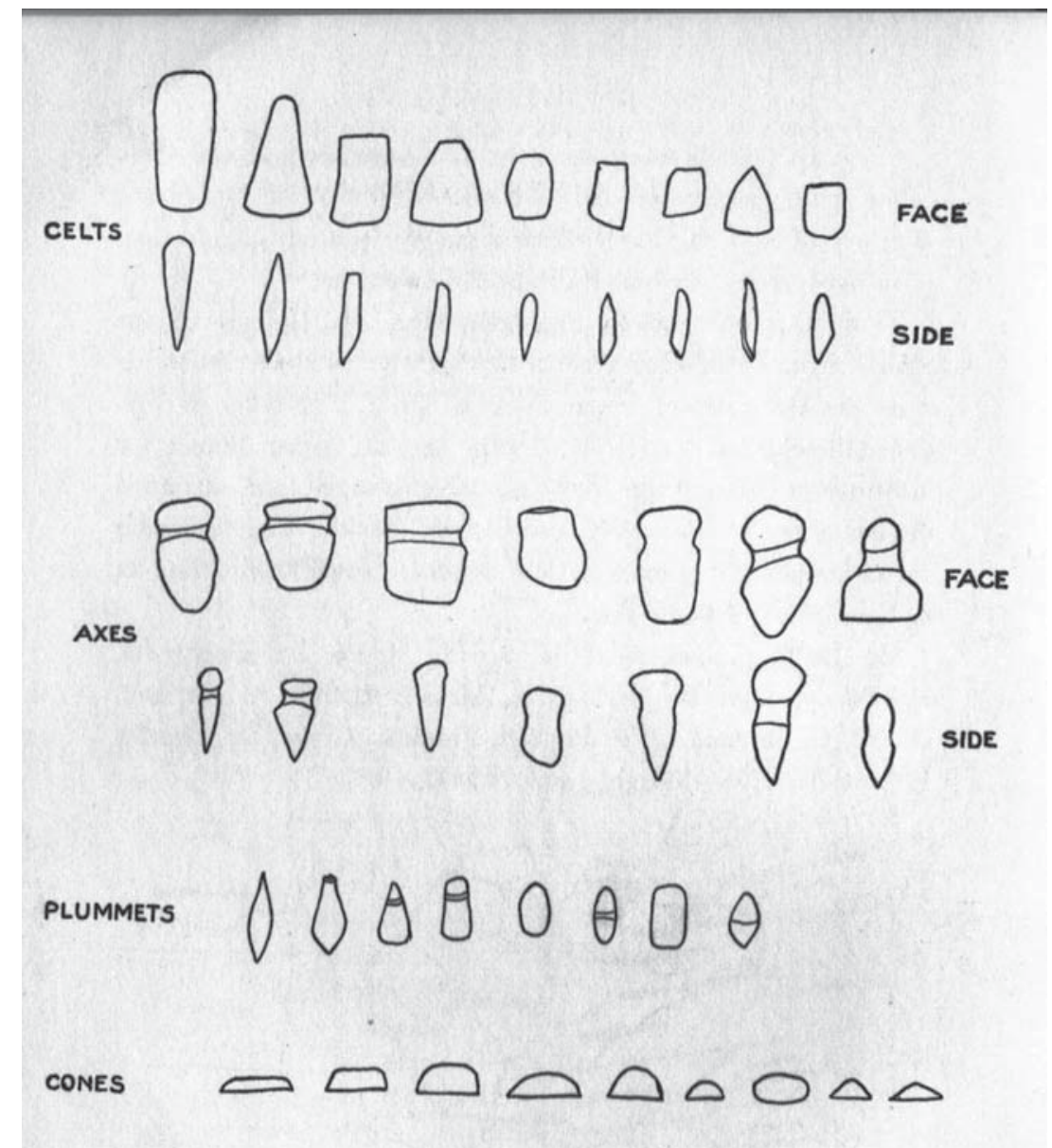

Figure 2. Outlines of hematite types.

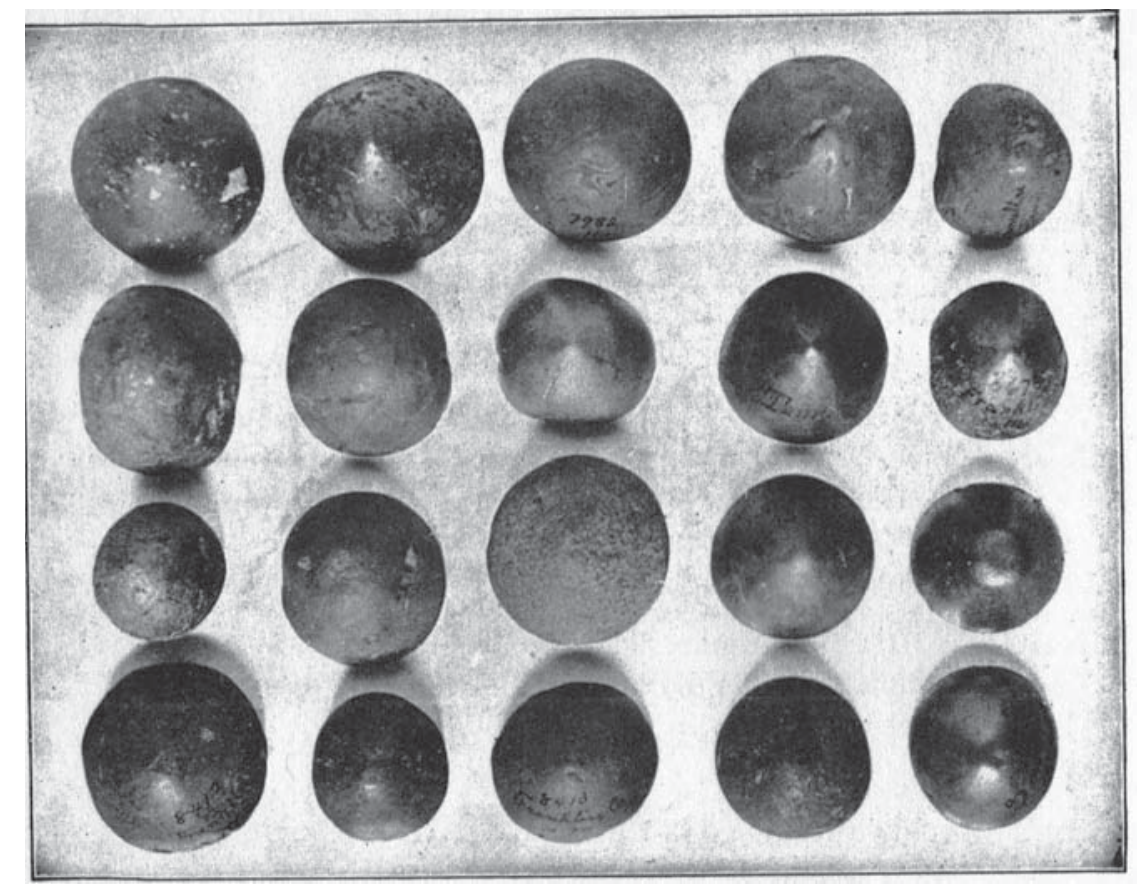

Figure 3. Hematite cones. 


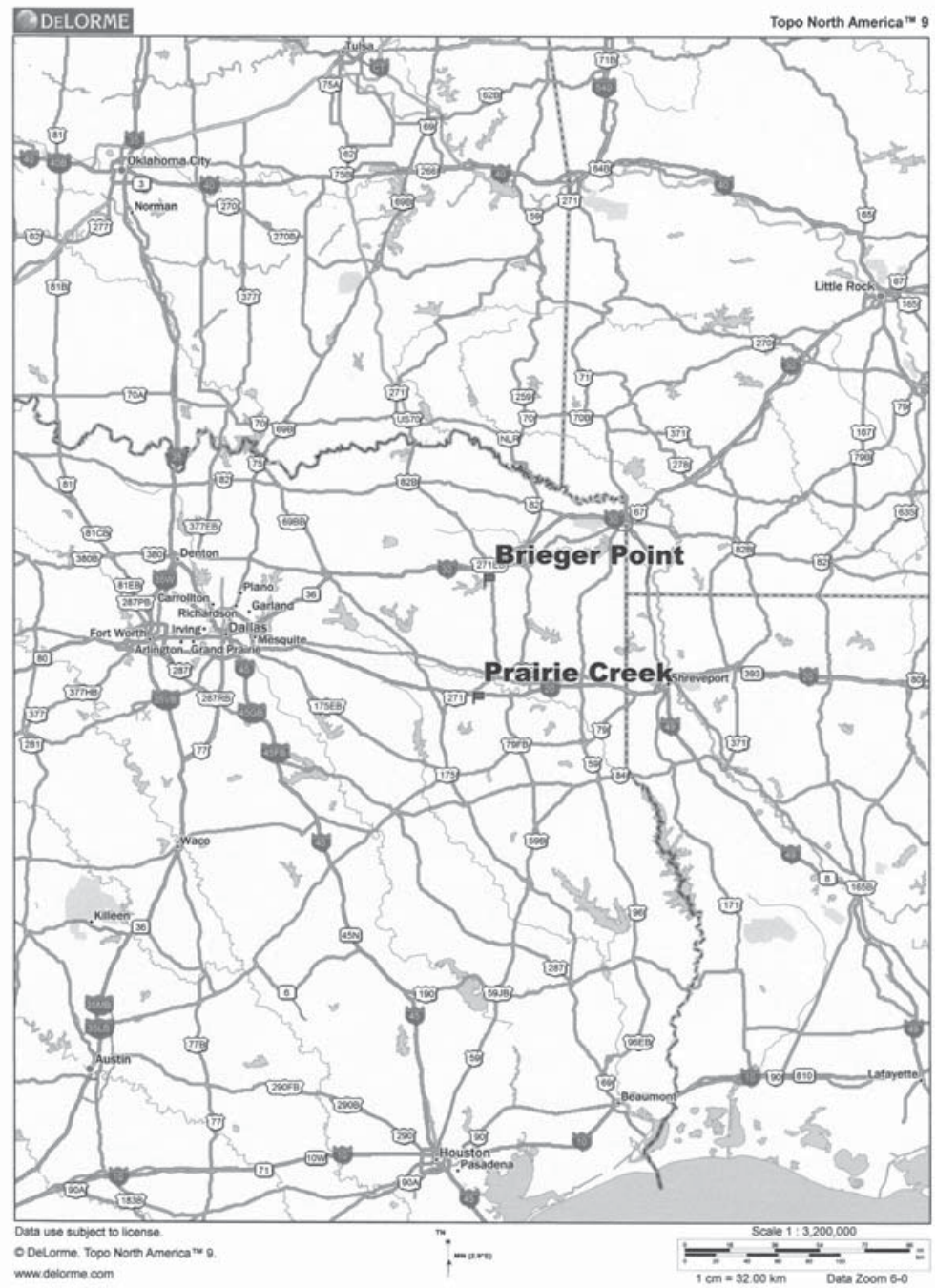

Figure 4. Location of Prairie Creek and Brieger Point sites.

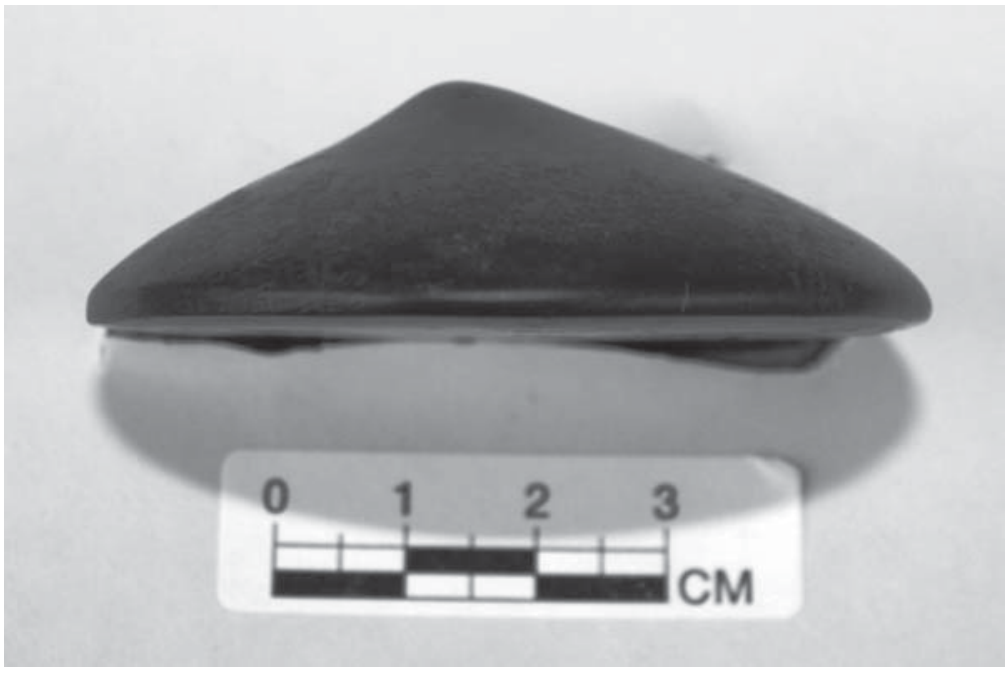

Figure 5. Profile view of Prairie Creek cone. 

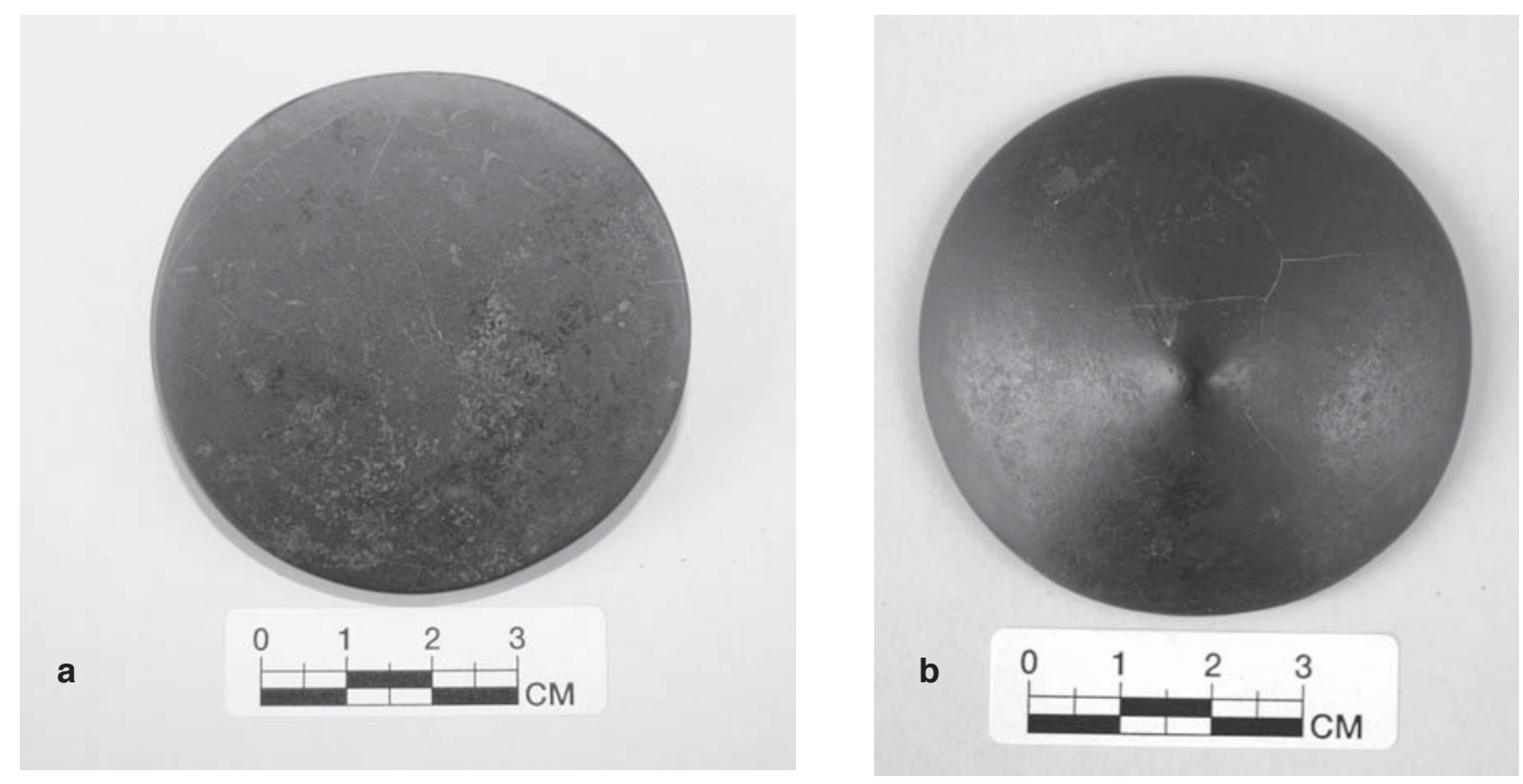

Figure 6. Prairie Creek cone: a, bottom view; b, top view.
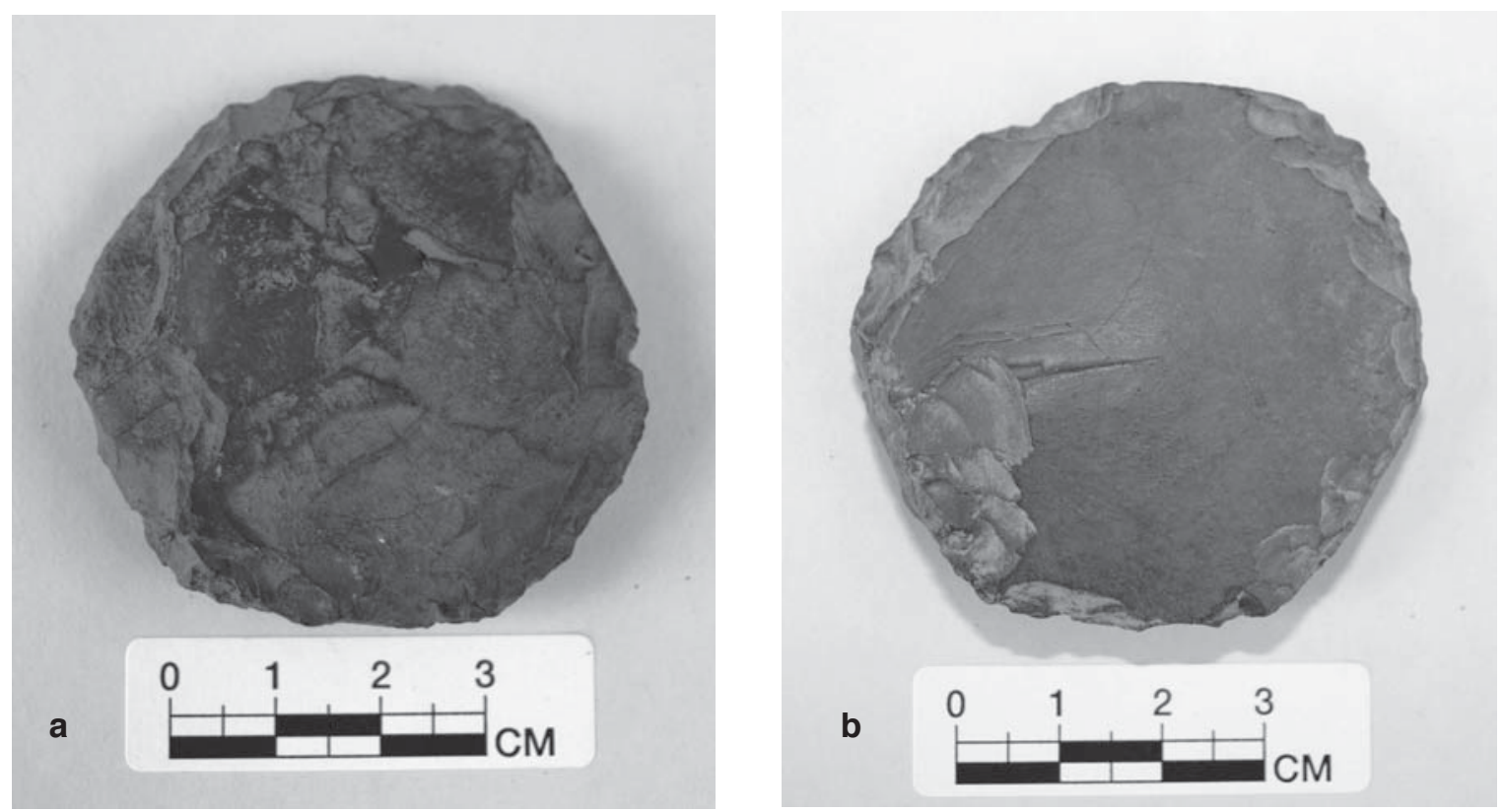

Figure 7. Brieger Point cone: a, top view; b, bottom view.

form. The cone is $54.3 \mathrm{~mm}$ in diameter from top to bottom and $50.8 \mathrm{~mm}$ diameter from side to side. It is uncertain why the object was never completed. 


\section{CONCLUSIONS}

A hematite cone object was found in Smith County, Texas, and a second possible cone (preform) was recorded at the Brieger Point site in the Big Cypress Creek basin. Heretofore, there has been no record of hematite cones having been found in East Texas, although polished hematite grooved axes, celts, pendants, nutting stones, and manos are well-documented in the region. Hematite cones, as well as other hematite objects, seem to be more prevalent in the central portions of the United States where raw materials are more common. Unfortunately, there is no way to date the two examples cited in this article or a way at present to associate them temporally or culturally with other hematite objects found in East Texas. It is possible to state that the hematite cones are made from similar materials and with similar workmanship. The precise workmanship and high degree of polish on some of these objects, including the Prairie Creek cone, indicate that they were more than just ordinary tools.

\section{ACKNOWLEDGMENTS}

I would like to thank my good friend Bo Nelson for providing me information about the Brieger Point cone.

\section{REFERENCES CITED}

Kraus, E. H., W. F. Hunt, and L. S. Ramsdell

1951 Mineralogy: An Introduction to the Study of Minerals and Crystals. McGraw-Hill Book Company, Inc. New York.

Moorehead, W. K.

1912 Hematite Implements of the United States Together With Chemical Analysis of Various Hematites. Department of Archaeology, Phillips Academy, The Andover Press, Andover, Massachusetts.

Nelson, B. and T. K. Perttula

2003 Archeological Survey along the Lake Bob Sandlin Shoreline, Camp, Franklin, and Titus Counties, Texas. Report of Investigations No. 46. Archeological \& Environmental Consultants, LLC, Austin.

Turner, R. L.

2006 Hematite Axes of Northeast Texas. Bulletin of the Texas Archeological Society 77:1-32.

Walters, $\mathrm{M}$.

2006 Walters Farm, Smith County, Texas. Journal of Northeast Texas Archaeology 25:40-56. 